Received: $26 / 01 / 2019$

Revision: 08/12/2019

Accepted: $14 / 12 / 2019$

OnlineFirst: $14 / 02 / 2020$

\title{
Establishing the Profesionalism of Geography Teacher through Authentic Assessment Field Study
}

\author{
Aris Munandar \\ SPd, M.Si Post Graduate Student Universitas Pendidikan Indonesia, Lecturer Faculty of \\ Social Science Universitas Negeri Jakarta, Indonesia, arisbrebes77gmail.com \\ Enok Maryani \\ Prof. Dr, MS, Post Graduate Lecterur Universitas Pendidikan Indonesia, Indonesia, \\ enokmaryani@upi.edu

\section{Dede Rohmat} \\ Prof, Dr, Post Graduate Lecterur Universitas Pendidikan Indonesia, Indonesia, \\ dederohmat64@gmail.com

\section{Mamat Ruhimat} \\ Dr, M.Pd, Post Graduate Lecterur Universitas Pendidikan Indonesia, Indonesia, \\ mamatruhimat@upi.edu
}

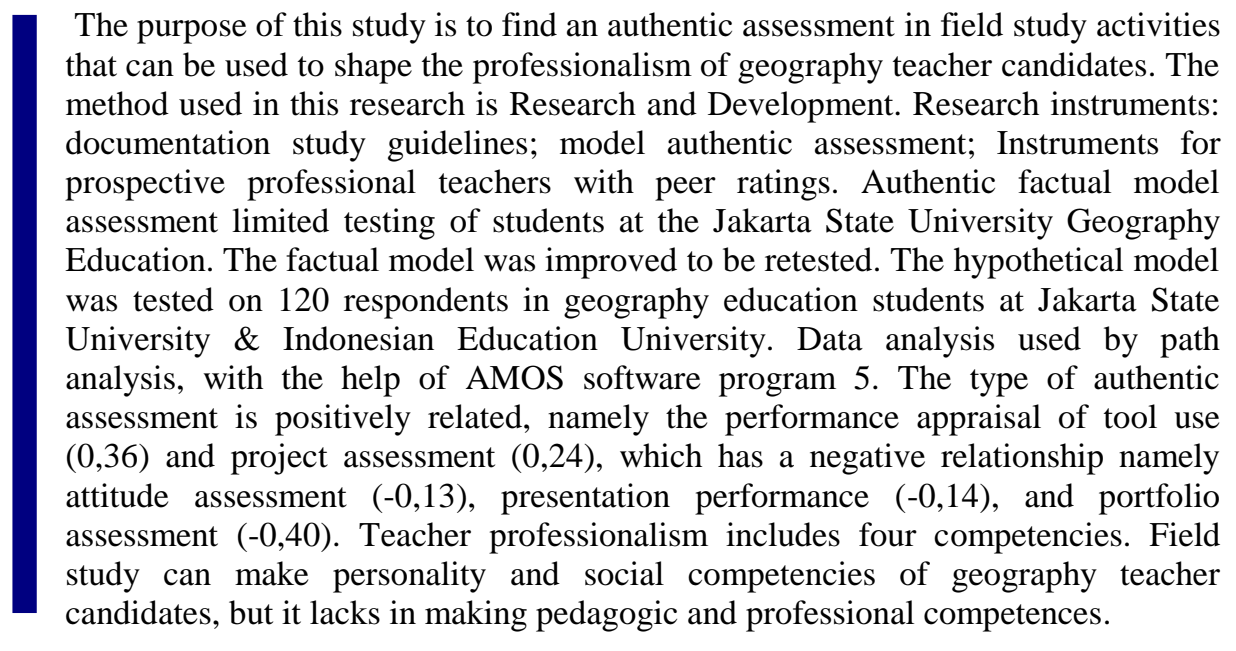

Keywords: professional teacher, geography teacher, field study, authentic assessment, geography

Citation: Munandar, A., Maryani, E., Rohmat, D., \& Ruhimat, M. (2020). Establishing the Profesionalism of Geography Teacher through Authentic Assessment Field Study. International Journal of Instruction, 13(2), 797-818. https://doi.org/10.29333/iji.2020.13254a 


\section{INTRODUCTION}

More than a quarter of geography teachers outside Java are taught by teachers who are not of geographic background (Gerber \& Chuan, 2000). The quality of graduate teachers depends on the quality of the teacher who produces the teacher (Goodwin \& Kosnik, 2013). Teacher-producing institutions consistently evaluate and test practices to guarantee graduates become a professional teacher (Djonko-Moore \& Joseph, 2016). Higher education has an important role in preparing prospective professions (Agevall \& Olofsson, 2013). Teacher education as professional education related to specific work and academic fields of study (Nilsson-Lindstrom \& Beach, 2013).

Knowledge of prospective teachers is obtained from pre-service education, pedagogical skills are obtained when teaching practice (Solbrekke \& Englund, 2014). Teachers need to be trained so they can integrate knowledge and skills in certain contexts as professional manifestations (Ball \& Forzani, 2009). The description of graduates' competencies can be seen from the curriculum used. The main curriculum structure seen is the teacher, learner, and assessment (Azim \& Khan, 2012). Review of the curriculum is a strategic key for the university in guaranteeing its graduates by proving an assessment profile that can inform stakeholder needs (Bosco \& Ferns, 2014).

Development of professional abilities for graduates by looking at the curriculum structure that can be elaborated in the course. One program that is unique to geography education in field activities. Field activities such as fieldwork by many staff as the heart of geography (Gold el al, 1991). Good geography teaching must now include fieldwork (IAAM, 2013). Fieldwork must enter into all levels of education level (Gerber \& Chuan, 2000). Fieldwork can improve participants' understanding to be able to develop specific, transfer skills, encourage more active learning and connect theory to the real world (Max, 2009). Fieldwork provides opportunities for learning not like imitation in class but can improve the understanding of concepts and geographic features and develop specific skills (HMI, 1992). There is an effective relationship between the response of students in terms of emotions and the value of learning that is more profound when carried out field study (Fuller, Edmondson, France, Higgitt, \& Ratinen, 2006). Fieldwork offers students the best concept of association with academic disciplines, and that is essential for acquiring the generic and subject-specific skills that will equip them for future employment (Stokes, Magnier, \& Weaver, 2011)

Meanwhile, the assessments which have been carried out are not in accordance with the characteristics of field activities.The use of written examinations on fieldwork is not appropriate (Lambert \& Reiss, 2015). Different forms of fieldwork assessment are more effective. (Gerber \& Chuan, 2000). The standard assessment used in the fieldwork is not in accordance with the field conditions, because more knowledge like the one in the textbook, is lacking in attitude assessment (Lai \& Lam, 2013). Attitude assessment is not done to see the performance of participants in the field study (Yeung \& Kong, 2009). There is a difference in the effectiveness of the form of assessment in fieldwork. (Kent Et. El, 1997). Based on the research results of Mulyantari (2005), field study in the form of Field Work Lecture I of the Department of Geography at Semarang State University concluded, there still needs to be an authentic assessment component. 
The application of authentic assessment is not only at one level of ability or discovery process but can develop high-order thinking skills (Azim \& Khan, 2012). Field study requires an assessment procedure and a supportive atmosphere between staff, participants, curriculum, institutions, and other related to this field activity (Fuller et al., 2006). Automatic assessments are carried out with complex activities and centered on student activities that produce products as well as developing tests and projects (Olfos \& Zulantay, 2007). The authentic assessment in fieldstudy is important because of the complexity of its activities. The fieldstudy involves physical and mental activities before, during and after going to the field.

The formation of professional teachers is a shared link between curriculum, pedagogic and assessment (Lambert \& Reiss, 2015). Through authentic assessment, it is expected that competencies can be formed in creating professional teacher candidates. Fieldwork is useful in understanding concepts, developing skills, developing values, respecting environmental norms and personality and social development(Lobo, 2007). Professional teacher required to have several abilities and competencies (Suyanto et al, 2013)

\section{CONTEXT AND REVIEW OF LITERATURE}

\section{Field Study}

Words 'field' It can be defined \& zone within a subject where supervised learning can take place via the first-hand experience, outside the constraints of the four-wall classroom setting (Maskall \& Stokes, 2008). The use of the term fieldwork in geography often occurs which is confused with field trips, picnics, outings, excursions (Lewis, 1968). The use of fieldwork is still debated, in this case, the field study is defined as 'fieldwork' may include field teaching, field trips, field research or field camps (Dando \& Wiedel, 1971).

Fieldwork is a structured experience of students studying outside the room, with objects such as buildings, geological sites, museums or places that are students' studies. Travel activities can be carried out several hours/days/stay several weeks to be able to conduct outcome learning assessments from students (Gerber \& Chuan, 2000). Fieldwork can be defined as learning activities by bringing direct experience on the actual field without any settings as in the classroom (Lobo, 2007).

Fieldwork design is influenced by the curriculum, educational theory, professional requirements, participant characteristics, funding sources, technology, motivation and time of staff/supervisors, location access, and equal opportunities (Maskall \& Stokes, 2008). Negative views of outdoor activities are related to the waste of funds, time and energy (Fuller et al., 2006). So that the implementation of the field study must really consider work frameworks (Daniella, 1997)

The search results of field study activities in several countries in Southeast Asia in the form of fieldwork activities (Gerber \& Chuan, 2000) show various variations in the implementation of their activities, namely field trip, fieldwork, and residential. The different types of field activities affect the length of implementation, participants, 
location, final product and assessment. Duration of activities related to the final product that must be reported and the form of assessment used.

\begin{abstract}
Authentic Assessment
Assessment is a term defined as the process of gathering information to make decisions about students, curriculum programs, education policies (Nitko, 1996). The term assessment is a synonym of assessment, measurement, testing, or evaluation. Assessment can be interpreted as a process to obtain information in any form that can be used to make decisions about students, both concerning curriculum, learning programs, school climate, and school policies (Uno, 2014). Based on some understanding of authentic assessment that has been elaborated by experts above, it can be concluded that authentic assessment is a process that involves various forms of measurement in the form of products and performance that reflect the learning of students both cognitive domains, effective or psychomotor.
\end{abstract}

Performance assessments are often also called alternative assessments or authentic assessments. Authentic assessment is usually aimed at looking at the appearance of students with obligations that are meaningful to education. (Nitko, 1996,). Assessment that connects teaching with complex and contextual real-life situations (Olfos \& Zulantay, 2007). Authentic assessment is often referred to as alternative assessment, if participants do, implement real-life tasks. However, not all alternative assessment techniques can be used in authentic assessment (Yusuf, 2015). Authentic assessment is developed to criticize the types of tests that usually produce superficial thinking without deeper learning (Olfos \& Zulantay, 2007).

Authentic assessment is best used in contexts such as the following: professional education programs; authentic clinical, production or research contexts; application and problem solving with preclinical concepts and laboratory work; Cross disciplinary integration (Macquarie University, 2008). Yusuf (2015) explained 9 characteristics of authentic assessment, namely: real-life and going on, since the beginning students understand the criteria that will be used in assessing assignments, valid and realistic, students structure and construct their own tasks, develop and prioritize HOTS (High Order Thinking Skill), authentic in real situations, comprehensive and integrated, emphasizing processes and products/results, prioritizing facts and direct evidence. Nitko (1996), explained the characteristics of authentic assessment to 4. Other opinions regarding the characteristics of authentic assessment were presented by Kunandar (2013).

Type of authentic assessment such as writing/report results, portfolio, checklist, observation/performance assessment, assessment of group projects (Olfos \& Zulantay, 2007). According to Maki (2004) which is included in the authentic assessment: portfolio, performance/performance, presentations, online learning notes, projects, case studies, professional practice, group projects, oral examinations. Whereas according to Yusuf (2015) the techniques in authentic assessment are 11, namely: observation, oral/open questions, class presentations, projects, assignments, journals, group work, 
portfolios, rubrics, interviews, focused groups, tests performance, trial/demonstration, debate/discussion, concept map, exhibition, poster.

Teacher professional development can be done in two ways, institutional cooperation models and individual/small group models (Reimers, 2003). Small group models have 15 of them, namely performance appraisal and portfolio. Based on the needs in the study in accordance with the preliminary study, then an authentic assessment that there are 4 uses assessment of performance, attitude, portfolio, and project.

\section{Teacher Professionalism}

Professionalism refers to the commitment of members of a profession to improve their professional abilities and continuously develop strategies used in doing work that is in accordance with their profession. Tilaar (2002) suggests that: A professional carries out his work in accordance with the demands of the profession or in other words, has the ability and attitude in accordance with the demands of his profession.

Competence is knowledge, skills and basic values reflected in the habit of thinking and acting (Zuldafrial, et al., 2004). Teacher competence is an illustration of what a teacher must do in carrying out his work in the form of activities, behaviors, and results that are shown in the teaching and learning process (Suyanto et al, 2013). Teachers who are skilled at teaching must certainly have a good person and be able to do social adjustments. (Hamalik, 2009).

Every country has a different standard of professionalism. In standard Australia 3 domains are used, namely: professional knowledge, professional practice, professional engagement. (Australia Institute for Teaching and School, 2014). In Ontario, Canada, professional standards teachers use 3 standards, namely: The ethical standards for the teaching profession, the standards of practice for the teaching profession, the professional learning framework for the teaching profession (College, 2016). This study refers to teacher competency in accordance with the Teacher and Lecturer Law No. 14 of 2005 and Government Regulation No. 19 of 2005 includes four competencies namely pedagogic, personality, social and professional competencies. Formation of prospective teachers through a series of learning processes carried out in the classroom and outside the classroom. The geography that has a unique field as a place to study. The field is the geographer's laboratory (Lewis \& Perce F, 1968). Fields in geography are very important in learning to be able to show, discuss, guide real thinking (Corey, 1968)

The number of activities field in each country is different. The number of field studies in the four universities (Jakarta State University, Indonesian Education University, Yogyakarta State University, Surabaya State University) has similarities, which are as many as 3 times conducted sequentially/technically (Munandar, 2017). The number of fields shows the importance of spaciousness in learning to provide hands-on experience. Learning is not only indoor, bringing out provides a direct experience that involves more of the five senses in learning. Involving many senses will take longer in the remembering process. In addition to field study activities in the form of street vendors/KKL, some subjects conduct outdoor activities such as field trips, excursions, excursions or other activities. In the UK, activities are almost the same as fieldwork for 
the age group of 13-15 years (50-70\%), ages 17-18 (80\%) (Lai \& Lam, 2013). Schools in the UK are 3 times more than in Brazil, indicating a gap developed and developing countries.

The relationship between the implementation of the field study and the formation of a geography teacher candidate can be illustrated with a graph. The field study activity scheme that will form the competency of professional teacher candidates consisting of four competencies namely pedagogic, personality, social and professional competencies.

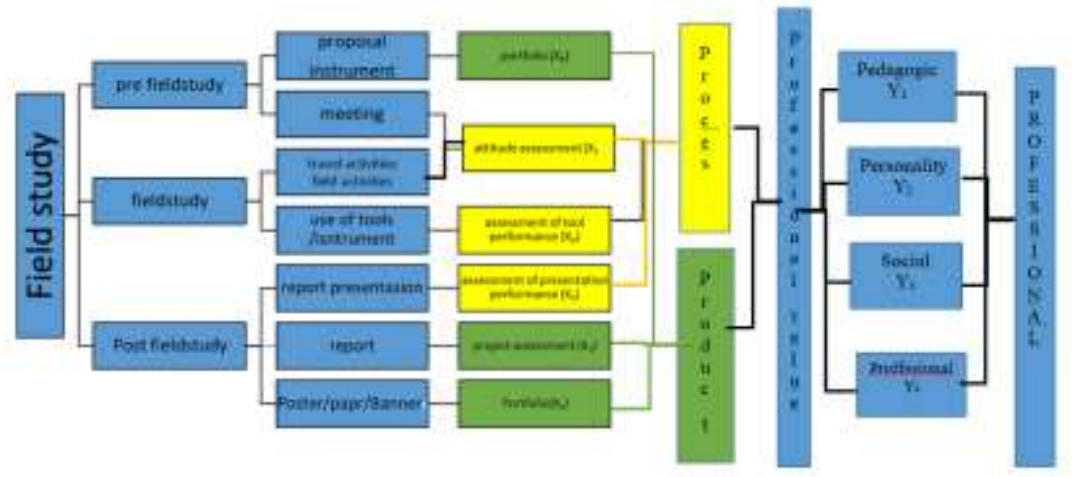

Figure 1

Model the Relationship between Authentic Assessment and Professionalism (adapted from Lai, 2013, and developed by the researcher)

\section{METHOD}

The model in this study used Research and Development: Research and information collecting, model planning, preliminary model development, limited trials of preliminary models, field trials, model revision as the result of field trials, operational field testing, final model revision, dissemination and implementation. (Borg \& Gall, 1983). The research subjects are students of Jakarta State University /Universitas Negeri Jakarta (UNJ) and Indonesian Education University /Universitas Pendidikan Indonesia (UPI) Geography Education Study Programs. The trial of factual models conducted in field study 2 in the Geography Education UNJ. The trial results of the improvement of the hypothetical model have carried out in UNJ and UPI Geography education. The population of the study was 450 students from the UNJ and UPI Geography education study programs. With quota sampling, there are six groups of 20 total samples of 120 respondents.

Secondary data in the form of Lecture Event Unit documents, Academic Handbook (Buku Pedoman Akademik/BPA), SOPs and other documents. Primary data from the trial results of authentic assessment models applied to students. Research instruments: documentation study guidelines; model authentic assessment in the form of attitude assessment, performance assessment, portfolio assessment, project assessment; Instruments for prospective professional teachers with peer ratings. Processing and analysis of research data using inductive analysis techniques through the use of path 
analysis techniques. Path analysis is done to see the relationship between the variables of prospective professional teachers. The coefficient path shows the strength of the relationship of the independent variables to the dependent. If the path coefficient is low, and the number is below 0.05 , then the influence of the pathway is considered low so that it can be eliminated. The relationship the path between variables in the path diagram is a correlation relationship, therefore the calculation of the path coefficient numbers uses the standard $\mathrm{z}$ score.

$$
r_{i j}=\frac{N \sum X Y-\left(\sum X\right)\left(\sum Y\right)}{\sqrt{\left[n \sum X^{2}-\left(\sum X\right)^{2}\right]\left[n \sum Y^{2}-\left(\sum Y\right)^{2}\right]}}
$$

- Path Coefficient:

$$
\rho_{i j}=\left(R_{i}^{-1}\right)\left(r_{Y_{i} X_{j}}\right) \quad t_{i}=C r_{i}=\frac{\rho_{i j}}{S E}=\frac{\rho_{i j}}{\sqrt{\frac{\left(1-R_{i}^{2}\right) C_{j j}}{n-k-1}}}
$$

- The coefficient of determination:

$$
R_{i}^{2}=\sum\left(\rho_{i j}\right)\left(r_{Y i X j}\right) F=\frac{(n-k-1) R_{i}^{2}}{k\left(1-R_{i}^{2}\right)}
$$

$\begin{aligned} & \text { where: } \mathrm{Cjj}=\begin{array}{r}\text { inverse } \\ \text { vause } \\ \text { correlation } \\ \text { matrix }\end{array} \\ & \text { element }\end{aligned}$
$\begin{aligned} & \mathrm{n}=\text { sample size; and } \mathrm{k}= \\ & \text { number of exogenous } \\ & \text { variables in the model or } \\ & \text { sub-structure tested. }\end{aligned}$

- Residual path coefficient:

$$
\rho_{e_{i}}=\sqrt{1-R_{i}^{2}}
$$

\section{FINDINGS}

\section{Research and Collecting information}

The result of preliminary tracer study is to reveal the similarity and the difference of the fieldstudy activity at each study program. The preliminary result is taken to make a factual model to observe the implementation of fieldstudy. The process assessment and the product from the result of preliminary study is as follow:

Pre-activity : the activeness at briefing, cooperation in group

Field activity : the activeness in the field

Post-field activity: final exam, report, final report presentation, leaflet, article, paper, banner

\section{Model planning (planning)}

Preliminary authentic assessment looked at the process assessment and the product of fieldstudy. The product which was resulted by every group of fieldstudy program was identified, analysed and its preliminary assessment instrument was made. The process and product assessments were conducted together at the time of fieldstudy 
implementation. The following table is a table describing the process and product assessments.

Table 1

The Process and Product Assessments of Field Study

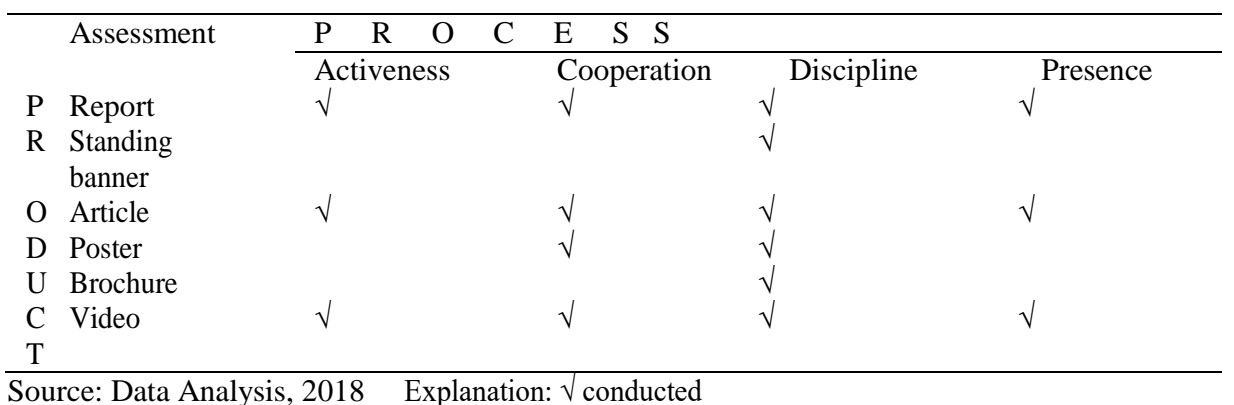

\section{Development of the preliminary model}

The preliminary model is developed by measuring the process and the product which was resulted. The process assessment is conducted by measuring attitudes that a participant must have before, during and after in the field. Meanwhile, the product assessment is in the form of a project and a portfolio. The factual model is as follows:

Table 2

Factual Model of Authentic Assessment

\begin{tabular}{|c|c|c|c|c|}
\hline Attitudes $\mathrm{X}_{1}$ & $\begin{array}{l}\text { Tool/instrument } \\
\text { performance } \mathrm{X}_{2}\end{array}$ & $\begin{array}{l}\text { Presentation } \\
\text { performance } \mathrm{X}_{3}\end{array}$ & $\begin{array}{l}\text { Report } \\
\text { Project } \mathrm{X}_{4}\end{array}$ & Portfolio $\mathrm{X}_{5}$ \\
\hline Activeness & Doing work steps & $\begin{array}{l}\text { Communication } \\
\text { effectiveness }\end{array}$ & Systematic & Proposal \\
\hline Discipline & $\begin{array}{l}\text { Use of } \\
\text { tools/instruments }\end{array}$ & $\begin{array}{l}\text { Participant's response } \\
\text { ability }\end{array}$ & Content & Content \\
\hline Sympathy/Caring & Work attitude & Entertaining/Humorous & Logic & logic \\
\hline Politeness & $\begin{array}{l}\text { Ability to analyse } \\
\text { works }\end{array}$ & Self-confidence & Scientific & scientific \\
\hline Cooperation & Accuracy & $\begin{array}{l}\text { Accepting critic/input } \\
\text { Use of speech style } \\
\text { Use of gesture } \\
\text { Use of focus view }\end{array}$ & & $\begin{array}{l}\text { Intrument } \\
\text { Content logic scientific } \\
\text { Poster } \\
\text { Content logic scientific }\end{array}$ \\
\hline
\end{tabular}

Source: Data Analysis, 2018

\section{A Limited Trial toward Preliminary Model}

Instrument model of factual assessment is tested on the fieldstudy implementation which was hold in Geography Study Program UNJ. The respondents were 20 students (of Geography UNJ) who took PKL. In general, the reliability test had Cronbach's alpha 0.858 , the validity test by comparing $r$ count to $r$ table. To measure $r$ table with significance $5 \%$ is by the formula $\mathrm{df}=\mathrm{n}-2$, where $\mathrm{n}$ is the total of sample. With the total respondents $n=20, d f=20-2=18$. For the number 18 , we can get $r$ table $=0.444$ which can be seen from the table of $r$ product moment at the significance $5 \%$. Then, the score of $r$ count is compared to $r$ table. If $r$ count is bigger than $r$ table, the statement is categorized as valid, or if $r$ count $>r$ table, the statement is valid. 


\section{Revision of Model from The Result of Field Trial}

Based on the findings in the field and in the discussion, $\mathrm{X}$ variable of factual model is revised, especially for the assessment of X1, many of which was not revealed. This assessment is improved by finding the similarity in $\mathrm{Y}$ variable, particularly in the personality and social competences. The attitude (variable) includes the value of religion in hypothetical model. Putting the value of religion in the attitude is a curriculum demand for the personality competence that the participant should have as the professional teacher, where in the 2013 curriculum included in the first core competence. The attitude variables consisting of activeness, cooperation, discipline are changed because they are not valid. The variables of presentation performance X3 are the effectiveness of communication, participant's response ability, entertaining, selfconfidence, accepting critic, and the use of speech style. The use of view focus is substituted for the others. The difficulty to collect data which are appropriate with the criteria makes the variable(s) changed. Then, they are added by a rubric of assessment that can measure each indicator. Each of $\mathrm{X}$ variable is made to be a rubric to get the assessment criteria which are determined by the Likert scale.

Table 3

Factual Model Development of Authentic Assessment

\begin{tabular}{|c|c|c|c|c|}
\hline Attitudes & $\begin{array}{l}\text { Tool/instrument } \\
\text { performance }\end{array}$ & $\begin{array}{l}\text { Presentation } \\
\text { performance }\end{array}$ & $\begin{array}{l}\text { Report } \\
\text { Project }\end{array}$ & Portfolio \\
\hline $\mathrm{X}_{1}$ & $\mathrm{X}_{2}$ & $\mathrm{X}_{3}$ & $\overline{X_{4}}$ & $\mathrm{X}_{5}$ \\
\hline Doing worship & Doing work steps & Intonation & Preparation & Proposal \\
\hline $\begin{array}{l}\text { Giving (Islamic) } \\
\text { greeting/salam }\end{array}$ & Use of tools/instruments & Use of gesture & $\begin{array}{l}\text { Collecting } \\
\text { data }\end{array}$ & $\begin{array}{l}\text { Instrumen } \\
\mathrm{t}\end{array}$ \\
\hline Tolerance in worship & Work attitude & $\begin{array}{l}\text { Use of Bahasa } \\
\text { Indonesia }\end{array}$ & $\begin{array}{l}\text { Analysing } \\
\text { data }\end{array}$ & $\begin{array}{l}\text { Poster/ban } \\
\text { ner/paper }\end{array}$ \\
\hline Sympathy/Caring & Ability to analyse works & $\begin{array}{l}\text { Visual aid/slide } \\
\text { show }\end{array}$ & $\begin{array}{l}\text { Report } \\
\text { writing }\end{array}$ & \\
\hline Politeness & $\begin{array}{l}\text { Accuracy } \\
\text { Work safety } \\
\text { Neatness of } \\
\text { tools/instruments } \\
\text { Cleanliness of } \\
\text { tools/instruments }\end{array}$ & & & \\
\hline
\end{tabular}

Source: Data Analysis, 2018

\section{Operational Field Trial}

Hypothetical model is widely tested. In hypothetical model, the validity test and the significance are conducted. The significance test is conducted by comparing $r$ count to $r$ table or comparing the score $p$ or sig to the level of significance. To measure $r$ table with significance $5 \%$ is by the formula $\mathrm{df}=\mathrm{n}-2$, where $\mathrm{n}$ is the total of sample. The result is $\mathrm{df}=120-2=118$. For the number 118 , we can get $\mathrm{r}$ table $=0.179$ which can be seen from the table of $\mathrm{r}$ product moment at the significance $5 \%$. Then, the score of $\mathrm{r}$ count is compared to $\mathrm{r}$ table. If $\mathrm{r}$, at $\mathrm{r}$ table, is < $\mathrm{r}$ count, the statement is valid.

A change is conducted in the attitude assessment of hypothetical model. The invalid and unreliable items are substituted. The sympathy/caring and politeness items in factual 
model that are valid and reliable still exist in the hypothetical model. The attitude assessment adds the item of participant's religion value. The addition of religion value is in accordance with the curriculum demand at school that requires invading the religion as one of the participant's core competences. Therefore, there are 5 total items which are measured in the attitude assessment.

Because the performance assessment in the use of instrument on factual model has 5 valid and reliable items, all of the items are used for hypothetical model. The assessment adds work safety, the neatness and the cleanliness of instruments. The performance assessment is also accompanied with a rubric to enable the process of assessment. The total items in the performance assessment are 8 (eight).

The presentation performance assessment has only one valid and reliable item, that is the use of gesture. The rest are invalid and unreliable so that they are substituted for hypothetical model. Presentation assessment gets a difficulty in data collection technique. The items in this assessment must be replaced with the others and the substitutions are explained in the form of a rubric of assessment. The total items in hypothetical assessment are 4 (four).

Project assessment are overall changed, from the beginning to the end of activity. In factual model the project assessment is only conducted in the end, but the project in hypothetical model is wholly assessed. The valid item in factual model is included in the end of activity and it is explained in a rubric. There are 4 items of the project assessment in total for hypothetical model. The project assessment is accompanied with a rubric of assessment.

Portfolio uses proposal, instrument and poster, each of them has 3 sub-indicators. The test result shows that only one item, poster content, is valid and reliable. The rest that are invalid and unreliable need to change. In the next stage it needs to change the items which are accompanied with a rubric. Because every group produces a different product, it is necessary to add the other products such as brochure/banner/paper. Proposal and instruments are still used, but their descriptions are changed and completed with a rubric.

\section{Final model revision}

The result of the previous stage is improved to be made as the final AAF consisting of an assessment of instrument performance, a project report, a different portfolio (poster, article, brochure and video). The final AAF can be seen in the following: 
Table 4

Final Model

\begin{tabular}{llll}
\hline No & Instrument Assessment & Assessment of project report & Project Assessment \\
\hline 1 & Do work steps & Preparation & Poster \\
2 & Use of tools/instruments & Collecting Data & Article \\
3 & Work attitude & Analysing Data & Banner \\
4 & Ability to analyse works & Report Writing & Brochure \\
5 & Accuracy & & \\
6 & Work safety & & \\
7 & Neatness of tools/instruments & & \\
8 & Cleanliness of tools/instruments & & \\
\hline Source: Data Analysis, 2018 & &
\end{tabular}

\section{Model Development}

The results of the preliminary study search to find out the similarities and differences in the implementation of field study activities in each study program. The aspects that are used as a search reference : products produced, assessment process of collecting data, the arrangement of reports. The results of the preliminary study were made a factual model to see the implementation of the field study. Hypothetical model is widely tested.

Hypothetical model is tested for validity and significance. Test significance was done by comparing $r$ count with $r$ table or comparing the value of $p$ or sig with the level of significance. To calculate the $\mathrm{r}$ table with a significance of $5 \%$ using the formula $\mathrm{df}=\mathrm{n}$ 2 , $\mathrm{n}$ number of samples. Results df $=120-2=118$, number 118 see table $\mathrm{r}$ product moment at a significance of $5 \%$, obtained by the number $r$ table $=0,179$. Results $r$ calculate compare the value of $r$ table. If $r$ is labeled $r<r$ the results of the calculation, eating the statement is valid.

Reliability testing using Cronbach's Alpha with numbers above 0.60 is considered reliable and can be continued with path analysis testing. If there is an indicator that has a value below $r$ table is deleted then striving to get the ideal relationship model.

Table 5

Reliability of Variables X and Y

\begin{tabular}{cllll}
\hline Variables & \multicolumn{4}{l}{ Cronbach's Alpha } \\
& Stage 1 & Stage 2 & Stage 3 & \\
\hline $\mathrm{Y}_{1}$ & $\mathbf{0 , 1 0 8}$ & 0,347 & 0,767 & Reliable \\
$\mathrm{Y}_{2}$ & 0,899 & 0,961 & & Reliable \\
$\mathrm{Y}_{3}$ & 0,88 & & Reliable \\
$\mathrm{Y}_{4}$ & 0,22 & & Not reliable \\
$\mathrm{X}_{1}$ & 0,634 & & Reliable \\
$\mathrm{X}_{2}$ & 0,708 & & Reliable \\
$\mathrm{X}_{3}$ & 0,708 & & Reliable \\
$\mathrm{X}_{4}$ & 0,708 & 0,742 & & Reliable \\
$\mathrm{X}_{5}$ & $\mathbf{- 0 , 2 4 9}$ & 0,641 & & Reliable \\
\hline
\end{tabular}

Source of data processing 2018 
From the table can be seen in stages 1 , variables $\mathrm{Y}_{1}$ and $\mathrm{X}_{5}$ have Cronbach's Alpha less than 0.60 so that invalid indicators are deleted. Variables $Y_{1}$ and $X_{5}$ each 1 invalid item deleted. Statement items in $\mathrm{Y}_{2}$ and $\mathrm{X}_{4}$ variables each 1 item also invalid deleted.

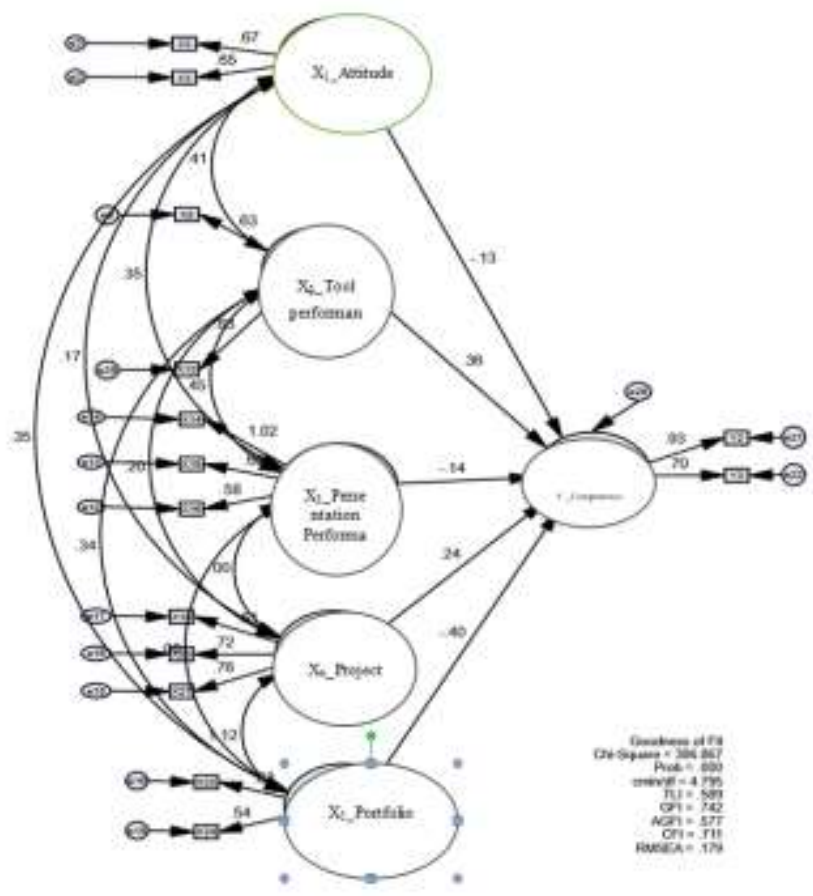

Figure 2

The Relationship between Variable X and Y after Striming

After all invalid items are deleted, the ideal relationship model is obtained with the path coefficient value as shown in the following table:

Table 6

Variable Path Coefficient X

\begin{tabular}{llll}
\hline Variable & \multicolumn{2}{l}{ Path coefficient } & Information \\
\cline { 2 - 3 } & stage 1 & stage 2 & \\
\hline $\mathrm{X}_{1}$ & $-0,14$ & $-0,13$ & Related - \\
$\mathrm{X}_{2}$ & 0,20 & 0,36 & Related + \\
$\mathrm{X}_{3}$ & $-0,06$ & $-0,14$ & Related - \\
$\mathrm{X}_{4}$ & $-0,16$ & 0,24 & Related + \\
$\mathrm{X}_{5}$ & $-0,8$ & 0,40 & Related - \\
\hline
\end{tabular}

Source of data processing 2018

From the table, it can be explained that variable $\mathrm{X}_{2}$ (equipment performance assessment) and $\mathrm{X}_{4}$ (project assessment) have a positive relationship with the formation of professionalism in geography teacher candidates. Variables $\mathrm{X}_{1}$ (attitude assessment), $\mathrm{X}_{3}$ 
(presentation performance assessment) and $\mathrm{X}_{6}$ (portfolio assessment) have a negative relationship to the formation of professional geography teacher candidates. The negative meaning in this relationship, meaning that if used it will reduce the process of forming professional geography teacher candidates.

$\mathrm{Y}$ variable (professionalism of geography teacher candidates) consists of 4 competencies namely $\mathrm{Y}_{1}$ (pedagogic competency), $\mathrm{Y}_{2}$ (personality competency), $\mathrm{Y}_{3}$ (social competency) and $\mathrm{Y}_{4}$ (professional competence). Variables $\mathrm{Y}_{1}, \mathrm{Y}_{2}, \mathrm{Y}_{3}$ use peer assessment, while $\mathrm{Y}_{4}$ uses a 30 multiple-choice test, each for 3 packages for 3 groups in the field study. As a result, pedagogical and professional competencies cannot be formed in the implementation of field study. $Y_{2}$ and $Y_{3}$ variables have a high relationship with values of 0.93 and 0.70 . The calculation results show that the variables $\mathrm{Y}_{1}$ and $\mathrm{Y}_{4}$ have a number below 0.50 indicating that this competency has a low relationship. The professional competencies $\left(\mathrm{Y}_{4}\right)$ test results showed an average value of 56.84 with the lowest value of 44 and the highest of 77 . The test results showed more in the medium category, none of which were low and few with high categories. The test results can be seen in the following graph

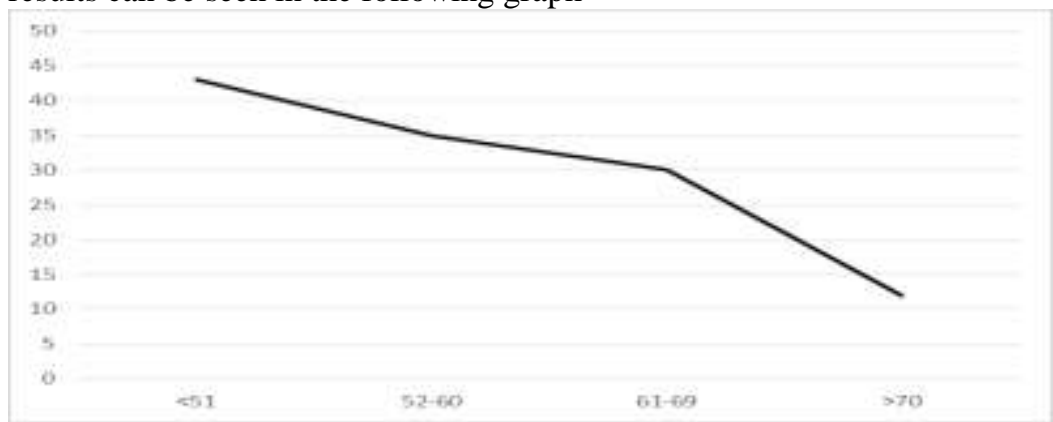

Figure 3

Graph of the results of the professional competency test (Source: Survey 2018).

\section{DISCUSSION}

\section{Factual model}

Authentic assessment of factual model results from the preliminary survey. In general, the assessment is divided into two: process and product. Assessment of process consists of activity, cooperation, disciplinary and presence. Meanwhile, assessment of product is in the form of report, standing banner, article, poster, brochure, and video. Each university had a difference in the process and the product for the total of semester credits, the different weight and time of scoring. The total of credits for each group and these different credits, of course, made an impact on the classroom face-to-face interaction.

Factual model is made to accommodate the assessments of process and of product. The assessment of process is in the form of attitude and performance; meanwhile, the assessment of product is in the form of project and portfolio, proposal, instrument and poster. 
The result of attitude assessment is only two: sympathy and politeness. These items can be observed in the limited testing. The other items are difficult to observe in the field. Therefore, it needs a change. The attitude assessment is difficult because the researcher must really observe the participants' behaviour according to the expectation in the items of attitude assessment.

Overall, the performance assessment in the usage of equipment can be observed. As all items can be observed, there is no change. Some items are added to the next stage of testing. For the performance assessment of presentation, the only valid and reliable item is the gesture usage. Data collecting technique in the assessment of presentation got a difficulty since there is no rubric in describing the participants' behaviour. The items in this assessment must be substituted for the others. The explanation of the other items is in the form of assessment rubric.

Portfolio uses proposal, instrument and poster as the assessments. The only valid and reliable item is the content of poster so that all of the invalid and unreliable items must be changed. For the next stage it needs a change of the items and they should be accompanied with a rubric. As every group produces a different product, the other products such as brochure, banner or paper are necessary to add. For proposal and instrument, they still can be used, but the description is changed and completed with a rubric.

\section{Hypothetical Model}

Hypothetical model in the attitude assessment is changed. Sympathy and politeness in factual model which have validity and reliability are still available in the hypothetical model. The participant's religion value is added in the attitude assessment. This addition is in accordance with the demand of school curriculum which requires invading the religion as the one of the participant's core competences.

All items of the performance assessment in the usage of instruments in factual model have validity and reliability so that they, overall, are used in hypothetical model with the additional items: work safety, neatness and cleanliness of the equipment. The performance assessment is accompanied with the rubric to enable the assessment process.

The valid and reliable performance assessment of presentation is the usage of gesture. The other items which are invalid and unreliable are substituted in the hypothetical model. The items in this assessment must be replaced with the others and explained in the form of the assessment rubric. Project assessment is overall changed, from the beginning to the end of the activity. The project assessment in factual model is only in the end, but in the hypothetical model, the project is assessed overall. The valid item in factual model is included in the end of activity and is explained in the rubric. In hypothetical model the total of the items for project assessment is four (4). The project assessment is also added with the assessment rubric.

Portfolio uses proposal, instrument and poster. Each of them has three (3) sub indicators. The test result shows that only one item, content of the poster, is valid and 
reliable. The rest are invalid so that they must be substituted. In the next stage, there are changing items which are accompanied with a rubric. As every group produces a different product, it needs to add other products such as brochure/banner/paper.

\section{Final Model}

Final model is taken after hypothetical testing. Based on theoretical and empirical reviews, the final model is performance assessment, project assessment and portfolio assessment. Performance assessment is measured by observing the participants when they used the instruments. The supervisor observed 15-20 participants during the activity, from pre-field to post-field (project assessment), in the field (the instrument performance assessment) and their portfolio (after from the field). Then, the final model is as follow:

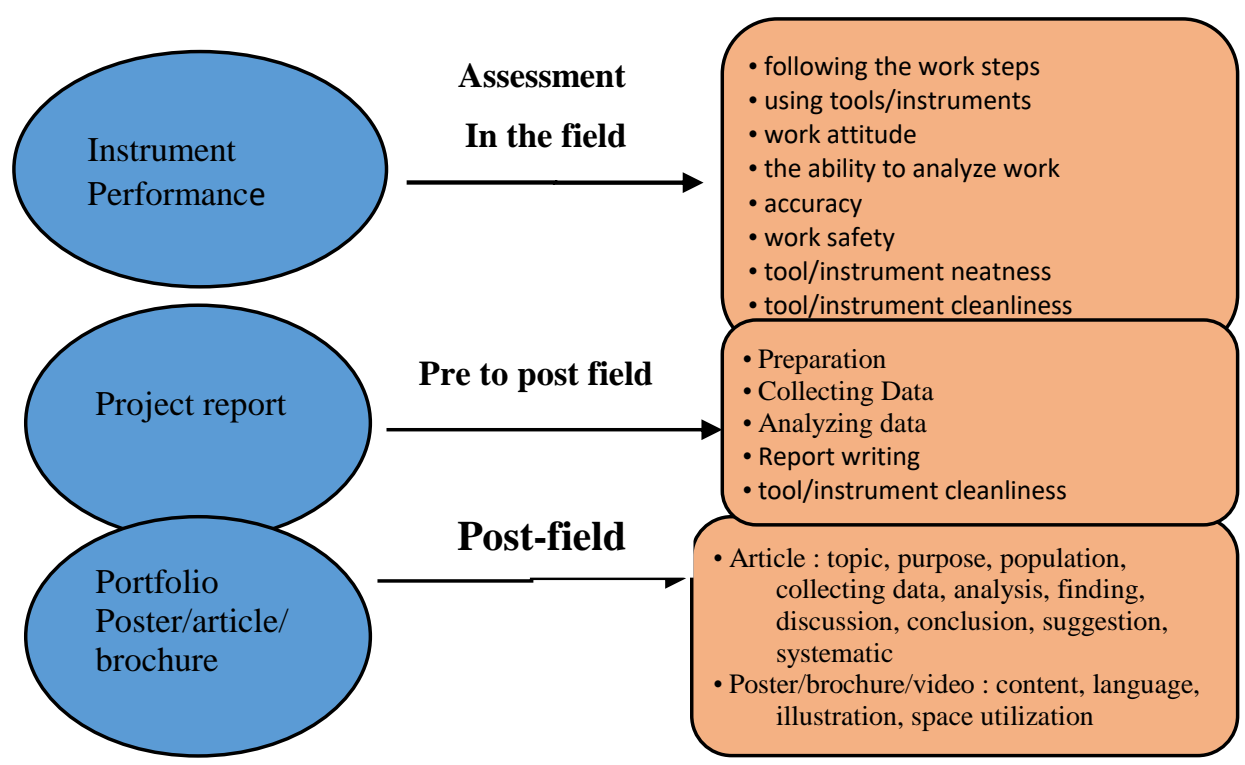

Figure 4

The Final Model of Authentic Assessment (Source of data processing 2018)

\section{Competency Formation}

The hypothetical test results show a low value of the relationship. Field study activities cannot form pedagogical competence in general. Pedagogic competencies are obtained from classroom learning activities (indoor) and other practical activities. Learning activities in the classroom, for example, in indicators of understanding students in-depth are obtained from educational learning activities that are taught various theories of learning that can later be applied in the field when practicing at school. Other indicators such as designing, implementing and evaluating learning will be obtained in educational subjects such as teaching planning, teaching and learning strategies, and teaching 
evaluation. Implementation of practice in schools will apply pedagogical competence. Pedagogical skills are obtained when teaching practices (Solbrekke \& Englund, 2014). The hypothetical test results show a high relationship value. Field study activities can form personality competencies in general. Authentic assessment of survey/questionnaire equipment performance, making a report project, either directly or indirectly forming the personality competencies expected of a professional teacher. Personality competencies that form a steady and stable personality, a mature personality, a wise personality and have a noble character. The results of field activities aim at developing interpersonal between participants, participants with mentors, developing selfconfidence, cooperation, adaptation (Lai, 2013). These findings are in accordance with the opinions of Hurlock (2005) about the characteristics of late adolescents aged 17-21 years. Authentic assessment of project types and performance forms personality competencies. Personality competencies with indicators can be formed through field study activities.

The results of the hypothetical model test show a high relationship value. Field study activities can form social competence in general. Social competence in communicating with the community is obtained from field data collection activities. Collecting government/resource/community leaders data on information requires effective communication. Facing various communities that have diverse characteristics requires effective communication in interviews. Respondents can train to speak to convey their intentions and objectives, listen to explanations, ask questions that certainly require habituation. The more communication that is interwoven with various different characters will train respondents to be able to practice communicating effectively. Social, economic, educational, cultural differences from the other person will train the respondent in communication. Current field study activities focus on aspects of the affective domain and enhancement of field study values (Fuller et al., 2006). Personal professional developments was the utilization of information and communication technologies (Balbağ, 2012)

Calculation results in unreliable pedagogical competence as a measuring instrument. Instruments made to measure participants' abilities cannot be used. Results with multiple choice tests showed the lowest score of 44 , the highest of 77 with an average of 56.84 . The difficulty in making this instrument is because the sample test site has the characteristics of a different field study. The emphasis on field study content in UNJ and UPI is different. The geography study program at UNJ, stage 1 field study emphasizes the study of physical geography, stage 2 emphasizes the study of human geography, namely socio-economic while stage 3 combines physical and human. Field study at UPI is like the stage 3 field study at UNJ, namely physical and human integration. Differences in each stage of the field study in the UPI Geography Department stage 1 identifies, stage 2 makes a comparison, and stage 3 solves problems. It is this difference in emphasis that causes instruments developed in professional competencies cannot be developed and continued as a measurement tool. Questions to find out the participants' knowledge must be done Repeated trials to obtain validity and reliability, so if you want to try it you have to make 6 different model instruments for each stage both at UNJ and at UPI. 


\begin{abstract}
Authentic Assessment
Path analysis attitude results negative (-0.13). The results of the study show that the attitude assessment directly does not contribute to the formation of the teacher's professionalism. The formation of the attitude of the prospective teacher is formed from the assessment of others attitude assessments are formed from projects and portfolios, often called nurturant effects. Respondents were given the task of making activity reports. The understanding of the effects of cooperation, responsibility, discipline, cooperation. Attitude assessment cannot be done directly but is accompanied to other activities. Nurturant effects help develop the attitudes and personality of prospective teachers (Zuldafrial, 2014). Development of social and personality aspects as "hidden agenda" in field activities (Lai \& Lam, 2013)
\end{abstract}

There are two performance assessments, namely assessment in using equipment/ questionnaires and assessments in presentations. Performance assessment using equipment/instruments has a positive relationship in teacher professional formation. Equipment in the field study is a survey tool such as GPS, theodolite, compass, hammer geology, thermometer, ambilevel, drone. This equipment is used in observation and mapping (Hart, 1968). Number limitations are not a problem in field study activities. Respondents will try several measuring instruments to retrieve field data. Even though the respondents cannot practice all the tools, they can try some tools that can hone skills in the use of equipment in the future. The use of equipment in accordance with the SOP (Standard Operating Procedure) will train in the formation of meticulous, procedural personality attitudes and conduct in accordance with the rules/norms. Performance appraisal using equipment has a positive relationship in the formation of professionalism of geography teacher candidates.

Assessment of presentation performance has a negative relationship in the formation of the professionalism of geography teacher candidates. Assessment of presentation performance, when done, cannot be maximal, because only a few participants present, so that participants who do not make presentations cannot be assessed. Not all respondents who were selected made presentations both at the initial activity during and after the activity. It should be conveyed so that presentations are carried out from preimplementation and post-field with different people so that all experience in turns. The assessment criteria are distributed first to the participants so that before working on the assignment the participants already know the benchmark of assessment (Yusuf, 2015).

Project assessment has a positive relationship with the formation of professionalism in geography teacher candidates. Project assessment in the form of a final report. All study programs require activity reports as bills that need to be completed after the field study. This project report must be submitted to get value. Project reports have almost the same arrangement for all groups of respondents. Respondents must work together to be able to find primary/direct or secondary sources of data needed for field studies. Respondents must be able to complement the acquisition of data to be processed, analyzed and conclusions drawn. Technical and non-technical constraints faced in the process of collecting, processing, and reporting must be resolved together. This series of project activities contribute to social competence and personality. Participants have an attitude 
of responsibility, independence, acting in a beneficial manner, being open, accepting new things. These values are in the competence of professional teachers.

Portfolio assessment has a negative relationship with the formation of professionalism in geography teacher candidates. Portfolios are assessed in the field study, namely proposals, instruments, articles and posters. Proposals cannot be made portfolios because the proposals are not representative of the chosen respondents. Making proposals made by several people do not represent the chosen respondents. Proposals cannot be made authentic. The instrument cannot be used as a portfolio assessment. The instrument in stages 1,2,3 in UPI there are similarities in phase 3 of the UNJ, stages 1 and 2 have differences. The cause is not supporting the portfolio, because the model cannot be used for all groups. The portfolios produced from each group have different results. The UPI Geography Department portfolio produced for the three field study groups has similarities in the form of proposals, instruments, brochures, articles. The field study 1 group in the UNJ study program required participants to make a standing banner. The field study 2 group in the Geography Study Program at UNJ requires participants to make articles and posters. Field study group 3 Geography Study Program at UNJ requires participants to make articles. This difference in the portfolio is what causes the lack of this product in shaping professionalism. There should be uniformity in the products produced by field study activities. The model developed does not accommodate the diversity of products produced by each group. It is also necessary to create portfolio instruments that are specific to the characteristics of each product produced. So that it will be able to contribute to the formation of professional teacher candidates. Portfolio has weaknesses, among others, too many variations of instruments (Kunandar, 2014).

The picture shows the relationship between the use of performance assessment (using tools and tidiness of instruments/ instruments), project assessment (project preparation, data collection and reporting) to be individual or jointly forming personality and social competencies. Personality competencies that are formed are having a stable and stable personality, authoritative, noble character, wise and mature. The social competence that is formed is being able to communicate with other people such as colleagues, parents and the community. The use of other assessments can be done by matching the groups of field study activities. 
Figure 5

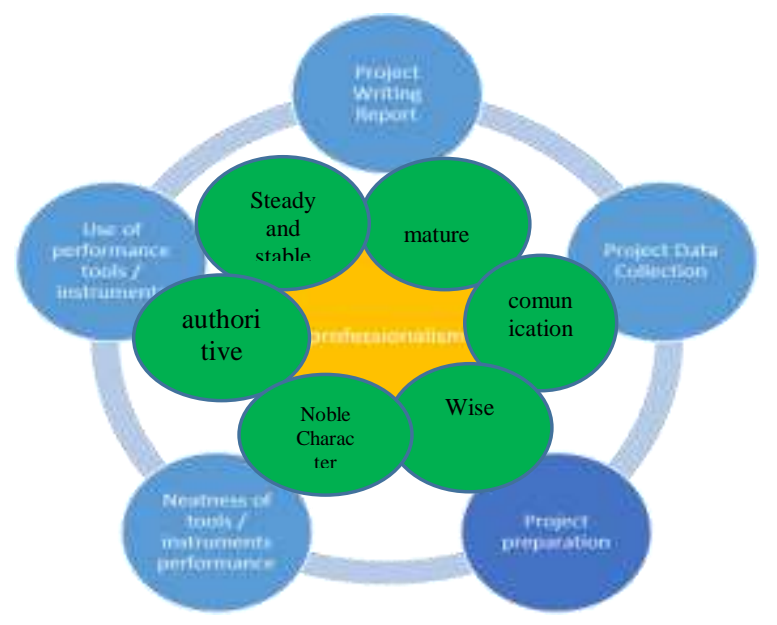

Showing Relationships using Performance Appraisal and Projects Forming Personality and Social Competencies

\section{CONCLUSION}

The results showed a positive relationship between the use of authentic assessment and the formation of professional geography teacher candidates. Authentic assessment that is positively related, namely performance appraisal of tool use and project evaluation. The use of authentic assessment which has a negative relationship, namely attitude assessment, performance assessment on presentations and portfolio assessments. Attitude assessment cannot be used directly but through the effects of effects. Portfolio assessment does not significantly shape the professionalism of prospective teachers, because the model developed cannot accommodate the amount and type assessed. The products produced are different, making it difficult for the assessment process. Presentation performance evaluations cannot be used because participants who make the same respondent presentations for each stage of the activity are pre, implementation and post field studies.

The competencies which are formed are personal and social. Professional competence with the test, less can be formed with an average value of 56.84. Pedagogic competence is also less formed in the developed model The formation of pedagogical competencies can be formed in learning activities in the class in the educational subject and applied later on when teaching skills practice in schools.

\section{REFERENCES}

Agevall, O., \& Olofsson, G. (2013). The Emergence of the professional field of higher education in Sweden. Professions \& Professionalism, 3(2), 1-22.

Australia Institute for Teaching and School. (2014). Australian Professional standards 
for teachers. Education Services Australia, (February), 1-28. https://doi.org/10.1177/002248715901000125.

Azim, S., \& Khan, M. (2012). Authentic assessment: An instructional tool to enhance students learning. Academic Research International, 2(3), 314-320. https://doi.org/10.1016/S1386-1425(00)00483-2.

Balbağ, M. Z., Yenilmez, K., \& Turgut, M. (2017) Personal professional development efforts scale for middle school mathematics teachers: An adaptation study. International Journal of Instruction, 10(4), 325-342.

Ball, D. L., \& Forzani, F. M. (2009). The work of teaching and the challenge for teacher education. Journal of Teacher Education, 60(5), 497-511. https://doi.org/10.1177/0022487109348479.

Bosco, A. M., \& Ferns, S. (2014). Embedding of authentic assessment in workintegrated learning curriculum. Asia-Pacific Journal of Cooperative Education, 15(4), 281-290.

College, O. (2016). Foundations of Professional Practice Ontario College of Teachers Ordre des enseignantes et des enseignants de 1' Ontario, (August).

Corey, Kenneth E. (1968). The role of field work in geographic research and instruction. In K. E. Corey, H. J. Fraser, H. A. David, \& S. Neil (Eds.), Field training in geography. Association of American geographers commission on college geography technical paper no 1. (pp.3-10). Washington, DC: Association of American Geographers.

Dando, W.A. \& Wiedel, J.W. (1971) A two-week field course with deferred papers: A possible solution to the problem of undergraduate fieldwork. Journal of Geography, 70, 289-293.

Daniella T., \& Micheal, W. (1997). Teaching and learning geography. London and New York: Routledge.

Djonko-Moore, C. M., \& Joseph, N. M. (2016). Out of the classroom and into the city: The use of field trips as an experiential learning tool in teacher education. SAGE Open, 6(2). https://doi.org/10.1177/2158244016649648.

Donni Juni Priansa, (2015). Manajemen Peserta Didik dan Model Pembelajaran, Penerbit Alfabeta Bandung

Fuller, I., Edmondson, S., France, D., Higgitt, D., \& Ratinen, I. (2006). International perspectives on the effectiveness of geography fieldwork for learning. Journal of Geography in Higher Education, 30(1), 89-101. https://doi.org/10.1080/03098260500499667.

Gerber, R., \& Chuan, G. K. (Eds.). (2000). Fieldwork in geography: Reflections, perspectives and actions. Springer. https://doi.org/10.1007/978-94-017-1552-2. 
Gold. J. R., Jenkins, A., Lee, R. Monk. J. Riley. J., Shepherd. I. D.H. \& Unwin. D. J. (1991). Teaching geography in higher education. Oxford: Blackwell.

Goodwin, A. L., \& Kosnik, C. (2013). Quality teacher educators = quality teachers? Conceptualizing essential domains of knowledge for those who teach teachers. Teacher Development, 17(3), 334-346. https://doi.org/10.1080/13664530.2013.813766.

Hamalik, O. (2009). Pendidikan Guru Berdasarkan Pendekatan Kompetensi, Bumi Aksara Jakarta.

Hart, J. F. (1968). The undergraduate field course. In K. E. Corey, H. J. Fraser, H. A. David, \& S. Neil (Eds.), Field training in geography. Association of American geographers commission on college geography technical paper no 1. (pp.27-38). Washington, DC: Association of American Geographers.

HMI (Her Majesty's Inspectorate). (1992). A survey of geography fieldwork in degree courses. Sler 1990-Summer 1991: A report by HM/. Report 9/92/NS (Sranmore: Her Majestyv Inspectorate. Department of Education and Science).

Hurlock, E. B. (2005). Perkembangan Anak Jilid 1, Erlangga, Jakarta.

IAAM (The Incorparated Association of Assistant Master. (2013). The teaching of geography in secondary schools. Cambridge University Press.

Kent, M., David, D., Gilbertson, Chris O Hunt. (1997). Fieldwork in geography teaching: A critical review of literature and approaches. Journal of Geography in Higher Education, 21 (3), 313-332. https://doi.org/10.1080/03098269708725439.

Kunandar. (2014). Penilaian Autentik (Penilaian Hasil Belajar Peserta Didik Berdasarkan Kurikulum 2013), Rajagrafindo Persada, Bandung

Lai, K. C., \& Lam, C. C. (2013). School-based assessment of fieldwork in hong kong: Dilemmas and challenges. Geography, 98(1), 33-40.

Lambert, D., \& Reiss, M. J. (2015). The place of fieldwork in science qualifications. School Science Review, 97(359), 89-95.

Lewis, P. F. (1968) On field trips in geography, in: Association of American Geographers (Ed.) Field Training in Geography, Technical Paper 1, Commission on College Geography (Washington, DC: Association of American Geographers).

Lobo, B. N. (2007). Student Journals and a Geography Fieldtrip in Costa Rica . An assignment for the "Issues of Concern in Geographic Education" Module, 1-45.

Macquarie University. (2008). Creating authentic assessment. Learning and teaching centre. Retrieved from https://pdfs.semanticscholar.org/3e72/4d1091d7328b64ba4c10ca061a459477fcfa.pdf.

Maskall, J., \& Stokes, A. (2008). Designing effective fieldwork for the environmental and natural sciences. GEES teaching and learning guide. Retrieved from http://www.gees.ac.uk/pubs/guides/fw2/GEESfwGuide.pdf. 
Max, H. (2009). The importance of direct experience: A philosophical defence of fieldwork in human geography. Journal of Geography in Higher Education, 33(2), 169182. https://doi.org/10.1080/03098260802276698.

Mulyantari. (2005). "Kuliah Kerja Lapangan (KKL) I Geografi Sebagai Salah Satu Metode Pembelajaran Kontekstual dan Pengaruhnya Terhadap Prestasi Belajar Mahasiswa Pendidikan Geografi“. (skripsi). Jurusan Geografi. FIS. UNES. Semarang.

Munandar,Aris. (2017), P erbandingan Kegiatan Fieldstudy di Program Study/Jurusan Pendidikan Geografi (Study di UNJ, UPI, UNESA, UNY), Jakarta, Univesitas Negeri Jakarta.

Nilsson-Lindstrom, M., \& Beach, D. (2013). The professionalization of the field of education in Sweden: A historical analysis. Professions and Professionalism, 3(2), 117. https://doi.org/http://dx.doi.org/10.7577/pp.560.

Nitko, A. J. (1996). Educational assessment of students. New Jersey Prentice-Hall.

Olfos, R., \& Zulantay, H. (2007). Reliability and validity of authentic assessment in a web based course. Educational Technology and Society, 10(4), 156-173.

Maki, Peggy L, (2004), Assessing for learning, building a sustainable commitment across the institution. Virginia: Sterling.

Reimers, E. (2003). Teacher professional development: an international review of the literature. UNESCO: International Institute for Educational Planning, 1-197. Retrieved from http://unesdoc.unesco.org/images/0013/001330/133010e.pdf.

Solbrekke, T. D., \& Englund, T. (2014). Certification of teachers: Tensions in a new signature reform. Professions and Professionalism, 4(2), 1-13. https://doi.org/http://dx.doi.org/10.7577/pp.668.

Stokes, A., Magnier, K., \& Weaver, R. (2011). What is the use of fieldwork? Conceptions of students and staff in geography and geology. Journal of Geography in Higher Education, 35(1), 121-141. https://doi.org/10.1080/03098265.2010.487203.

Suryanto, Asep Jihad, (2013), Menjadi Guru Profesional strategi Meningkatkan Kualifikasi dan Kualitas Guru di Era Globalisasi, Jakarta, Essensi.

Tilaar, H. A. R. (2002). Membenahi Pendidikan Nasional. Jakarta: PT. Rineka Cipta.

Uno. Hamzah B. (2014). Belajar dan Pembelajaran. Semarang. IKIP Pres .

Yusuf, Muri. (2015), Asesmen dan Evaluasi Pendidikan, Pilar Penyedia Informasi dan Kegiatan Pengendali Mutu. Jakarta. Prenamedia Group.

Zuldafrial, M. Lahir, (2014). Profesi Kependidikan Guru Dalam Perspektif UndangUndang Nomor 14 Tahun 2005, Yogyakarta, Media Perkasa. 